\title{
Admirative In Turkish, Albanian And Romanian Languages
}

\author{
Dr. Xhemile Abdiu \\ University of Tirana \\ abxh_1@yahoo.it
}

\section{DOI:10.5901/mjss.2014.v5n19p634}

\begin{abstract}
Turkish admirative mood presents a different structure comparing with the same mood in other languages. This mood exists even in Albanian and Romanian languages. As it's known they have their own characterictics of the way in which they are formed, their structures and the stylistic values. In this paper we will talk about the stylistic value of this mood in Turkish, Albanian and Romanian languages. We will try to explain the structure of this mood in these languages and will try to explain the use of this mood in different contexts giving examples from each languages. The Turkish admirative doesn't influence in admirative mood of Albanian, Bulgarian and Romanian languages. In Albanian language the admirativ mood presents an authentical mood that is very different from this mood in Turkish. In Romanian languages we have some partical contexts in which this mood is using and a different structure of it. Each language has its own structure and stylistical values. We will try to distinguish the differences between the way of expressing in admirative mood in these languages and giving examples comparing these structure.
\end{abstract}

Keywords: Admirative Mood, Structure,The Stylistic Value, The Position In The Sentences.

\section{Introduction}

Mood is a grammatical category of the verb expressing modality. Its meaning is the attitude of the speaker towards the content of the message.

The most frequently cited instance of Turkish grammatical influence in The Balkan is that of the development of the category of "reportedness" in the verbal system of some forms of east South Slavic, including standard Bulgarian and standard Macedonian. These two languages, just like Turkish, distinguish between processes directly perceived (witnessed) by speaker and processes not so perceived. (Kazazis, 1972: 98-99)

Admirative can be defined as the use of a special form or the special use of a form to express the speaker's surprise. In Balkan Slavic (Bulgarian and Macedonian), Albanian and Turkish such forms are all related to the perfect in some fashion, either synchronically or diachronically. Ex.Toj bil bogat. Ai qenka i pasur. O zengin imiş. (Friedman 1980: 7) The admirative mood in Albanian, different from other languages is a separate series of paradigmatic sets rather a special use of an already existing form. In Albanian language we have admirative mood which includes present, imperfect, perfect and plurperfect (example verb "be" and "have" - qenkam, qenkësha, paskam qenë, paskësha qenë, paskam, paskësha, paskam pasur, paskësha pasur) and nonadmirative mood which includes present, imperfect, perfect and plurperfect (example verbs "be" and "have" - jam, isha, kam qenë, kisha qenë, kam, kisha, kam pasur, kisha pasur).

According to Demiraj the admirative mood in Albanian is derived from an inverted perfect with a truncated participle (Demiraj 1971: 32).

The Albanian admirative was first labeled as such and described by A. Dozon in 1879 (cited by Demiraj 1971, 31), where he defines it as a group of "compound tenses" expressing surprise and admiration, sometimes ironic. Mayer used the term modal in referring to the admirative (Demiraj 1971, 32). In the century or so since Dozon's grammar, this has been the only essential change in the traditional description of the meaning of the Albanian admirative, viz., a mood expressing surprise, etc. (Friedman 1980: 17)

According to Sytov, the admirative in Albanian language has specific features and attributes in comparison to other Indo European languages and non-Indo-Europeans. This grammar category has a special status and is part of a 
paradigm structure of verbs with many forms. Its basic meaning is its strong modality. It is used by the speaker to express a subjective assessment of real events, where the relations expressed by the admirative forms are combined with the real relations which the speaker established with the real and unreal. This can be found out by a series of forms, tenses an even moods (demostrative, subjunctive, conditional). This is what makes Albanian language special. (Sytov, 1979: 95-96)

The Albanian verbal system provides an instructive contrast to Balkan Slavic in its treatment of evidentiality. Albanian possesses two series of indicative tense forms, traditionally labeled indicative mood - mënyra dëftore and admirative mood - mënyra habitore, Nonadmirative and Admirative. (Sytov 1979, 110-111; Friedman 1981).

According to translations (see Friedman 1982), the vast majority of Albanian present admiratives correspond to Balkan Slavic simple presents, while most Balkan Slavic indefinite pasts correspond to Albanian nonadmirative past tense forms. (Friedman 1986: 182)

Most Balkan Slavic examples with "be" and "have" corresponding to an Albanian present admirative represent a use of the indefinite past to refer to a state which has been true before but was only discovered by the speaker at the moment of speech. (Friedman 1986: 183)

In Turkish language existed the suffixes -mış, -miş, -muş, -müş that has three grammatical functions. This suffix forms the perfect participle, which has no nonconfirmative nuances (belirtisiz geçmis zaman). According to linguists the three grammatical functions of the suffix -mış, -miş, -muş, -müş in modern Turkish are. 1- Stressed, attached directly to the verbal base or stem, used nonpredicatively with suffixes in addition to person markers, -mış, -miş, -muş, -müş forms the perfect participle, which has no nonconfirmative nuances. 2- Stressed, attached directly to the verbal base or stem, used only predicatively and only with person markers, -mış, -miş, -muş, -müş forms the past tense which the majority of grammarians say is nonconfirmative, 3- the -mış, -miş, -muş, -müş past of the verb "be", 3 sg imiş, can be used enclitically and added to almost any kind of predicate, in which case it is never stressed and is said to be unmarked for tense (Lewis 1967, 101-103, 122-124, Swift and Agrali 1966, 202-204, Deny 1920, 355, Elove 1941, 337, Calabov 1949, 88, Johanson 1971, 63, Kononov 1956, 250, 391) (Friedman 1980: 21)

Examples adapted from Friedman (Friedman, 1980: 21) translated in Albanian.

1.Gelmiş oğlan güzel(dir). - The boy who has come is handsome (Having-come boy handsome (is) - Djali që ka ardhur është i bukur. 1

2.Güzel oğlan gelmiş. - I gather the handsome boy has come/came (hand-some boy came/has come) - Djali i bukur ka ardhur/paska ardhur. 2

3.Oğlan güzelmiş. - The boy is/was said to be handsome. (Boy handsome is/was) - Djali qenka i bukur. 3

4.Güzel oğlan gelmişmiş. - The handsome boy is/was said to have come (Handsome boy having-come-is/was.

- Djali i bukur paska ardhur. $1+3$

As has already been noted, the -mış, -miş, -muş, -müş past has often been compared with the past indefinite of Balkan Slavic. (Lewis 1967, 101, (Kreider 1968, 104, Underhill 1976, 104, Lewis 1963, 110) (Friedman, 1980: 21)

The admirative use of imiş has received almost no attention in Turkish grammars and it has been mistakenly claimed that such usage not exist in Turkish (Debraekeleer 1966: 267). The examples cited in grammars and articles by foreigner linguists we will translate in Albanian (Friedman 1980: 22)

Ne çok kitabın varmış. - How many books I (seem to) have! Sa shumë libra paske! (Underhill 1976, 199)

Ben çok güzelmişim. (Kononov 1956, 391) - Why, I'm very beautiful! U sa e bukur qenkam (Qenkam shumë e bukur).

Ne güzel vallahi kösk gibi bir evmiş. (Kononov 1956, 391) - O Lord, how beautiful ... it's a house like a place! Sa bukur qenka një shtëpi si vilë.

Pek masallah... ne pek alim fazıl adam imiş. (Deny 1920, 727) Praise be! What a very learned and virtuous man he is! Mashallah qenka/paska qenë një burrë i ditur.

Of, ne güç hal imiş. (Deny 1920, 726) Uf sa situatë e rëndë paska qenë. (Friedman, 1980: p. 22) 
Many grammars omit reference to such usage altogether, and those which do cite it treat it as an emotive non confirmative of surprise. In Albanian language they are translated with the admirative forms (present and perfect).

The subjective modality or the modality composed of morphemes -mış, -miş, -muş, -müş, is otherwise called the retell mood or the narrative/dubitative mood. The subjective modality is used to express the personal attitude of the speaker towards what is being expressed in a sentence. -mış, -miş, -muş, -müş morphemes convey modal meanings and modify somehow the meanings of verbal moods. The subjective modality is composed of the past tense of the verb (imek) to be and undefinite form of suffix -(y)miş or the verb imiş joined to the forms of present tense.

According to Johanson these forms of subjective modality encompass characteristic meaning nuances. The speaker speaks of its own attitude towards what he/she telling. When translated to Albanian language or in other Indo-European languages this modality is expressed with special words which was told to the speaker by others, an action in which he/she did not participate and in consequence is not a participant and a witness of the event. In other words the element imiş with its subjective meaning influences the meaning of verbal tenses.

Johanson say that the indirectivity of Turkish Language is used in those sentences which have a contradictory meaning. It has been discussed that indirectivity is the linguistic expression of narrated event, as it is shown in the conscious subject. This means that the event has not been narrated directly but in an indirect way: referring to its reception from conscious subjects. The information source - the way/mood the event was made known to the conscious subject is not a criteria; it is nonessential (not a direct perception) whether perception was created through gossip, logic deduction or direct perception. Receiver is not necessarily speaker, but it can be also a partecipant in the narrated event. In consequence, the indicators or indirectivity are not included within the obvious scheme, making a difference between the speaker at first hand and information at first hand.

The functions of morpheme -mış, -miş, -muş, -müş are generally misunderstood in Turkish. It main meaning is often not exactly "gossip" or "supposition". It is wrong to define it as "personally unperceived event", it is wrong to pretend that it always expresses not a testimony, that shows the result of an unobserved process where the speaker was not present during the course of the event and does not testify to its occurrence, that the speaker was not the conscious source of the event and that the event is developed without the conscious participation of the speaker. (Kononov, 1980: 188) Besides the indirect mood of presentation, morpheme -mış, -miş, -muş, -müş does not always define experimented and unconscious events. Morpheme -mış, -miş, -muş, -müş from old Turkish language is used as a clear post-terminal and at the same time as an indirective. So morpheme -mış, -miş, -muş, -müş is used to know the entire or partial written event from understanding the valid information from some post terminal points of orientation. Johanson says that the essential indirect understanding is the reception of an impression which creates awareness on the situation. Non-information has to do with the mental preparation of the speaker or the preceding expectations of the speaker. Depending on the source of information can observe three types of uses: perceptive use, inferential use (conclusion), use for reporting.

Linguist have emphasized that -dı, -di, -du, -dü marks an event considered as true by the speaker, while -mış, -miş, muş, -müş marks an event in which the speaker is not a direct witness. (Bazin 1966: 272-273); Bazin-Feuillet 1980; Johanson 1971: 63, 281).

In the perceptive uses of -mış, -miş, -muş, -müş the event is imaged to take place after decisive limit, but it is not essential if the speaker has experimented with the completion of its limit.

Acoording to Johanson the semantic of particle -(y)mış, -(y)miş, -(y)muş, -(y)müş in Turkish has often been misunderstood. It has been considered as "dubitative". -(y)mış, -(y)miş, -(y)muş, -(y)müş never conveys the post-terminal viewpoint, which is typical for -mış, -miş, -muş, -müş. So the combination of -(y)mış -(y)miş, -(y)muş, -(y)müş and intraterminal root with -iyor allows for intra-terminal point of view of the event, such as yazıyormuş. - Is/was writing. Besides, (y)mış -(y)miş, -(y)muş, -(y)müş is combined with -mış, -miş, -muş, -müş to denote and indirective post-terminality in a clear way (without ambiguity), for example in Turkish. Yazmışmış. - Has written.

The indirective as a category of admirative underlies the assertion that it is "indirect" when the act is not transmitted in a direct form, but in an indirect form a conscious subject. The result is information with double layer. The event is accepted by the speaker. The receiver can be the speaker as the participant in the conversation or as a participant in a transmitted act, such as the protagonist in a narration.

Admirative is the mood which expresses the existence of a series of tests for sourcing information. This information can be realised through gossip, conclusion and perception. 
Indirectivity in Turkish language is formed morphologically by two types of markers: Formal markers that are verbal suffixes which fill in the obligatory empty spaces and are in front of morpheme changes. -mış, -miş, -muş, -müş particles: enclitic elements which are normally found after the core objects and which fill in the empty spaces with zero morpheme.

In addition, Turkish language has particle imiş, which cannot be added to the verbal root but that can be followed by noun participles, including the verb noun roots. There is no clarity between the past and present time reference and the stable marker of indirectivity. As imiş normally presents allomorphs with suffixes such as -(y)mış, -(y)miş, -(y)muş, -(y)müş some of its meanings corresponding with the changing marker -mış, -miş, -muş, -müş.

In spoken language the variations of these morphemes are characterised by different structures of intonation. For example, present and imperfect tenses geliyormuş - is coming so it seems, future gelecekmiş - as it seems it will come and indirective i.e. gelmişmiş. - has already arrived.

In addition to the basic opposition between the -dı, -di, -du, -dü past and the -mış, -miş, -muş, -müş past, the copulative auxiliary verbs idi and imiş can be added to various verbal bases (aorist, progressive, future, perfect, conditional, necessitative, and subjunctive, e.g. gelir, geliyor, gelecek, gelmiş, gelmeli, geley) to add either a confirmative (di-) or nonconfirmative (miş-) nuance. The auxiliary idi always and the auxiliary imiş usually add an additional nuance of pastness, which can result in modal (e.g. irrealist), taxic (e.g. plurperfect), or other additional grammatical effects, but these are not essential to this exposition. The auxiliary idi can also be added to the any noun or verb (except the di- past, conditional, and imperative) to indicate either supposition or emphasis, depending on the context. When -dir is added to the third person -mış, -miş, -muş, -müş past, it results in a definite past tense, whereas when added to other persons the effect is one of supposition (see Lewis 1967: 106-41 and Johanson 1971: 229). Marked nonconfirmative meaning (admirative and dubitative, to be discussed below), are also conveyed by imiş. More recent analyses of the Turkish situation have emphasized the interaction of tense, aspect and mood in producing effects of evidentiality and certainty (see Aksu-Koç 1995).

The Romanian presumptive mood (modul prezumtiv) is said to express the same complex of meanings that occur in forms marked for nonconfirmative status in the Balkan language discussed so far, i.e. supposition, (ironic) doubt, surprise, report. The linguists debate about whether the presumptive is a separate mood. (see Friedman 1998). In romanian the presumptive generally indicates the availability of indirect evidence for the truth of a proposition.

According to Zafiu (2009), in Romanian, the label 'presumptive' dates from Manliu (1894: 248). As defined in Rosetti (1943: 77) and Rosetti and Byck (1945: 161), this label is used to refer to the expression of "an uncertain event, suspected only by the speaker" (See Mihoc, Romanian Presumtive Mood) Since many structures potentially fit this description, the Romanian Presumptive Mood has long been an object of controversy. Despite recent attempts to resolve the issue (in Romanian: Zafiu 2002, 2009, Reinheimer-Ripeanu 1994a,b, 2007; in French: Reinheimer-Ripeanu 1998, 2000; in English:Irimia 2009, 2010), many parts of the debate still remain open to discussion.

Traditional grammars (The Academy Grammar 1966, 2006) include this form among the non-indicative moods, besides the so-called conditional-optative and the subjunctive. What is puzzling about this 'mood' is its multiple combinatorial capacity; more specifically, it can be formed from the perfect form of the future (in its popular or literary constructions.) (See Irimia)

According to Irimia in Romanian, the so-called conditional-optative is realized, in its perfect forms, from idiosyncratic have/want auxiliary conjugations plus the infinitive of the verb be (fi), and the past participle; the perfect subjunctive has the marker SA followed by the infinitive be plus the past participle. The literary perfect future (indicative) is a combination of the auxiliary want followed by the infinitive be plus the past participle; the "popular" future has a similar composition, with the exception that reduced forms of the auxiliary want are employed. What makes the presumtive morphologically peculiar is that, instead of the past participle, the present participle (gerund) is added, which in Romanian has the characteristic suffix -nd.

According to Irimia presumptive forms constructed out of the conditional-optative are the most frequent, while the subjunctive ones are restricted to interrogative environments, with or without an interrogative particle.The presumtive is also possible in Romanian in embedded clauses introduced by impersonal.

A minimal semantic account of the Romanian presumtive has to explain where the indirect evidential meaning comes from. An answer this question starts from the observation that, similarly to some perfect evidentials exhibited by Bulgarian (Izvorski 1997) or Turkish (Aksu-Koç\&Slobin 1986), which also take a perfect morpheme, the Romanian ones are never 
interpreted as present perfect; as such, they do not accept adverbs generally preferred by the perfect (McCoard 1978, Izvorski 1997): at present, up till now, lately. The temporal and the aspectual behavior of the Romanian perfect morpheme suggests that it carries a strictly modal contribution, in a similar pattern to Bulgarian or Turkish. In the domain of evidentiality, the perfect is considered to be the spell-out of an exclusion (latridou 1996/2000) feature, responsible for extending the set of possible worlds quantified over beyond the set of epistemically accessible worlds, and giving rise to the evidential semantics.(See Irimia)

This is a general view of the admirativ and its specific features in Albanian, Turkish and Romanian languages. To make a comparision of the concept of admirative in this languages we based on the analize of a material which is the roman My name is Red of Orhan Pamuk translated in Albanian language.

\section{Method}

\section{Materials}

The materials for this study are selected from the literature in Albanian, in Turkish and in English languages about the concept of admirative and its development in Balkan area. They are respectively the material of Morphology in Albanian and Turkish. Also they are selected from the articles of Victor Friedman and Lars Johanson and other linguists which are wrote about this gramatical fenomena in Balkan area and altaic area. As we say we based on the traslation of admirativ mood in Turkish and Albanian language in order to give our opinion about the admirativ and its features in these languages. For Romanian the materials are less than materials from Turkish, Albanian and English languages. But we select only the subjunctive to make some teoritical conlusions.

\section{Procedure}

Firstly, we selected the materials from literature and try to make a general view of this fact in general meaning and after that in Albanian, in Turkish and partially in Romanian language. We try to emphase the paradigmatic sets of admirativ in Albanian, in Turkish and in Romenian based on gramatical fact collected into literature. For comparison we analize 150 pages of the roman "My name is red" in Turkish version and try to understand the structure of sentenses and the using of admirative with the mopheme -mış, -miş, -muş, -müş in this interval. We select the sentences and structures and try to find the respective translation in the Albanian version of this roman. It's obvious that these languages that are part of different families used a different structures to give the same meaning.

\section{Results}

In conclusion the admirative form has different structure and different origin in Albanian, in Turkish and in Bulgarian Languages. As a meaning and nuances these forms are similar in these languages. Turkish didn't influence on Albanian admirative or in Romanian Admirative. These forms are developed in different period of time and in different conditions. The presumptive in Romanian illustrate that is only a different type of evidential in the Balkan area. Albanian admirative mood is too old. It has developed into a marked non-confirmative. Albanian admirative has independent paradigmatic set. It is in inverted perfect. Albanian admirative developed a rich paradigm with different forms of the verb. The Turkish admirative has its characteristic and it is different from Albanian and Romanian language.

In material selected from the roman My name is Red we show that the most of the sentences are embedded sentences constructed with infinitive (noun sentences). The Turkish language has the infinitiv form that dosn't exist in Albanian language. This form that is very rich in Turkish language in Albania is traslated with conjuctive forms. As it is known the absence of infinitiv in Albanian language is replaced with the subjuctive mood. It means that the almost all the sentences with infinitiv of Turkish languages in Albanian are translated with the subjective mood.

The use of -mış, -miş, -muş, -müş of Turkish in admirativ meaning in Albanian are traslated with the admirativ mood's forms. Most of them are traslated with the present and perfect of admirativ in Albanian language.

The admirative even that it's the same morphological structure in these languages it is developed in different forms. The fact is that Turkish language did'nt affect the morphological structure of the Balkan languages. Turkish admirative didn't affect the Albanian admirative or Romanian admirative. These languages has a different elements and different forms to express the admirative meaning. 


\section{References}

Akademia e shkencave. (2002).Gramatika e Gjuhës shqipe I.

Akademia e shkencave. (2002).Gramatika e Gjuhës shqipe II.

Aksu-Koç, A.,\& Dan Slobin. (1986) A psychological account of the development and use of evidentials in Turkish, in W. Chafe - J.Nichols (eds.), Evidentiality: The linguistic coding of epistemology. (Advances in Discourse Processes 20.) NorWood, N.J.: Ablex 159-167.

Aksu-Koç, Ayhan A. (1988) The acquisition aspect and modality. The case of past reference in Turkish. Cambridge: Cambridge University Press.

Banguoğlu, T. (2000) Türkçenin Grameri.

Bayraktar, N. (2004). Türkçede Fillimsiler, TDK, Ankara.

Demiraj, Sh. (1969). Rreth disa problemeve të paskajores në gjuhën shqipe, Studime Filologjike, N.1.

Demiraj, Sh. (1971). Habitorja dhe mosha e saj, Studime Filologjike, N. 3.

Demiraj, Sh. (1971). Rreth zhdukjes së paskajores në gjuhën shqipe, SF.

Demiraj, Sh. (2004). Gjuhesi Ballkanike, Tiranë.

Deny, J. (1926), Turkish Grammer.

Ergin M. (1989). Edebiyat ve Eğitim Fakültelerinin Türk Dili ve Edebiyati Bölümleri için Türk Dil Bilgisi, Ankara, Bayrak Yayınları (18. Baski).

Friedman, V. A. (1978). On the Semantic and Morfological Influence of Turkish on Balkan Slavic Papers from the Fourteenth Regional Meeting: Chicago Linguistic Society. Chicago: Chicago Linguistic Society. 108-118.

Friedman, V. A. (1980). The study of Balkan admirativity: its history and development Balkanistica, Vol. 6, 7-30.

Friedman, V. A. (1981). Admirativity and Confirmativity in Zeitschrift für Balkanologie, Vol. 17, No. 1, 12-28.

Friedman, V. A. (1982). Admirativity in Bulgarian compared with Albanian and Turkish Bulgaria Past and Present, ed. by D. Kosev, Vol. 2. Sofia: Bulgarian Academy of Sciences. 63-67.

Friedman, V. A. (1986). Evidentiality in the Balkans: Bulgarian, Macedonian and Albania Evidentiality: The Linguistic Coding of Epistemology, (Advances in Discourse Processes, Vol. 20), ed. by Johanna Nichols and Wallace Chafe. Norwood, NJ: Ablex. 168-187.

Friedman, V. A. (1992). Aspectual oppositions in Bulgarian, Albanian and Turkish Săpostavitelno ezikoznanie, Vol. 17, No. 3, 33-38.

Friedman, V. A. (1993). Admirativity between modality and evidentiality Balkan Indirectivity: Diversity within Unity. Balkan Forum, Vol. 1, No. 2, 255-262.

Friedman, V. A. (1993). Balkan Indicativity: diversity within unity. Balkan Forum, Vol. 1, No. 2, 255-262.

Friedman, V. A. (1994). Turkisms in a comparative Balkan context Septième Congrès International d'Études du Sud-Est Européen: Rapports. Athens: Greek National Committee for Southeast European Studies. 521-543.

Friedman, V. A. (2010). The Age of the Albanian Admirative: A problem in Historical Semantics Ex Anatolia Lux: Anatolian and Indo-European Studies in Honor of H. Craig Melchert. ed. by Ronald Kim, Norbert Oettinger, Elisabeth Riecken, and Michael Weiss. New York: Beech Stave Press.

Gabain, A. V. (1988). Eski Türkçenin Grameri, Ankara: TDK Yayınları: 332, Çev.: Mehmet AKALIN.

Göksel, A. \& Kerslake. Turkish A Comprehensive Grammar.

Hengirmen, M. (1995) Türkçe Dilbilgisi, Ankara: Engin Yayınları.

Irimia, Monica-Alexandrina, The Romanian presumptive and its evidential nature. 
Johanson, L. (1995) On Turkic converbs clauses in: M. Haspelmath - E. Konig (eds.), Converbs in cross-linguistic perspective. Strukture and meaning of adverbial verb forms - adverbial participles, gerunds. (Empirical approaches to language typology 13.) Berlin - New York: Mouton de Gruyter, 313-347.

Johanson, L. (2002). Structural factors in turkic languages contacts, Curzon Press Richmond, Surrey.

Karahan, L. (2008). Türkçede Söz Dizimi, TDK, Ankara.

Kazazis, K. (1972). The Status Of Turkisms in the present day Balkan Languages.

Koç, N. (1998) A. N. Kononov'un Yeni Kipleri, Çağdaş Türk Dili Dergisi Şubat, 20-24.

Kononov, A. (1941). Gramatika Tureckobo Jazika, Leningrad - Akademija Nauk, Institut Vostokovedenjije.

Korkmaz, Z. (2007). Türkiye Türkçesi Grameri (Şekil Bilgisi), TDK, Ankara.

Kornfilt, J. Turkish Descriptive Grammars, London and New York.

Lafe, E. (1975). Mbi Habitoren dhe disa trajta të saj, Studime Filologjike, N. 2.

Lewis, G. L. (1975).Turkish Grammar Oxford, New York Oxford University Press, (Fellow of the British Academi emeritus professor of Turkish in the University of Oxford).

Likaj, E. (1987). Mbi format analitike në gjuhën letrare shqipe, SF, 1987, 3.

Mihoc, Romanian Presumtive Mood

Polisi, M. (2002). Gramatika e gjuhës turke (Fonetika dhe Morfologjia), Prishtinë.

Slobin, Dan I. \& Ayhan Aksu (1982) Tense, aspect and modality in the use of the Turkish evidential in: P. J. Hopper (ed.), Tense-aspect: Between semantics and pragmatics. Amsterdam, Philadelphia: Benjamins, 185-200.

Sytov, (1979). Kategorija admirativa v albanskom jazike I jeljo ballkanskije sootvjestvija, 95-96. 